\title{
EVALUATE THE EFFECT OF CIGARETTE SMOKING IN LIPID PROFILE, BODY MASS INDEX (BMI), BLOOD PRESSURE (BP), RESTING HEART RATE AND RR INTERVAL IN HEALTHY SMOKERS AND COMPARE IT WITH NON-SMOKERS
}

\author{
Chandmal Agarwal1, Rishabh Gupta², Puneet Rijhwani3 ${ }^{3}$ Shekhar Capoor ${ }^{4}$, Silky Singla 5
}

${ }^{1}$ Associate Professor, Department of General Medicine, Mahatma Gandhi Medical College and Hospital, Jaipur, Rajasthan. 2Junior Resident, Department of General Medicine, Mahatma Gandhi Medical College and Hospital, Jaipur, Rajasthan. 3 Professor and HOD, Department of General Medicine, Mahatma Gandhi Medical College and Hospital, Jaipur, Rajasthan. ${ }^{4}$ Assistant Professor, Department of General Medicine, Mahatma Gandhi Medical College and Hospital, Jaipur, Rajasthan. 5Junior Resident, Department of Dermatology, Venereology and Leprosy, Guru Nanak Dev Medical College and Hospital, Amritsar.

\section{ABSTRACT}

\section{BACKGROUND}

Cigarette smoking is an important and independent risk factor for atherosclerosis, coronary artery disease, peripheral vascular disorders, cerebrovascular diseases, cancer and for chronic obstructive airway disease (COAD). Several studies worldwide give the evidence that tobacco either chewed or inhaled alters the lipid profile in normal individuals. ${ }^{1,2}$ A recent prediction by World Health Organisation suggests that deaths in India may exceed 1.5 million annually by 2020 by tobacco consumption. ${ }^{3}$

The purpose of this study is to evaluate the effect of cigarette smoking in Lipid Profile, Body Mass Index (BMI), Blood Pressure (BP), Resting Heart Rate and RR interval in healthy smokers and compare it with non-smokers.

\section{MATERIALS AND METHODS}

50 healthy male subjects of age 20 - 45 years and 50 age matched male smokers attending Mahatma Gandhi Medical College and Hospital who had the history of smoking one or more cigarettes per day regularly for at least past one year. After taking an informed consent from the patient, a complete General and Systemic examination will be done following which Body Mass Index (BMI), ECG and blood test for serum lipids will be done. Total cholesterol, LDL (low density lipoproteins), VLDL (very low-density lipoprotein), TG (triglycerides), HDL (high density lipoprotein), ECG (RR interval), HR (heart rate) and BP (blood pressure) were recorded.

\begin{abstract}
RESULTS
Mean age in cases and controls is $34.42 \pm 6.68$. Statistically, this difference was insignificant ( $p>0.05)$. In our study, the mean value of total cholesterol level in smokers ranges between $136-201$ (mean $170.38 \pm 15.17$ ) and in non-smokers range between $140-182$ (161.69 \pm 11.18$)$. Statistically, this difference is significant ( $p$ value .001). In our study, the mean value of LDL cholesterol level in smokers ranges between $76-188$ (mean $118.44 \pm 35.770$ ) and in non-smokers range between $72-110$ (85.18 \pm 8.048 ) Statistically, this difference is highly significant ( $\mathrm{p}$ value $<.001$ ). In our study, the mean value of VLDL cholesterol level in smokers ranges between 21 - 33 (mean $24 \pm 2.35$ ) and in non-smokers range between $14-19$ (17.5.888 \pm 1.03 ). Statistically, this difference is highly significant ( $p$ value < .001). In our study, the mean value of TG in smokers ranges between $120-226$ (mean $149.58 \pm$ 46.141) and in non-smokers range between 110 - 136 (125.30 \pm 5.737$)$. Statistically, this difference is highly significant ( $p$ value < .001). In our study, mean value of HDL in smokers ranges between $27-47$ (mean $39.96 \pm 4.673$ ) and in non-smokers range between $31-52(42.74 \pm 4.526)$. Statistically, this difference is significant ( $p$ value $<.05)$. In our study, mean value of HDL in smokers ranges between 27 - 47 (mean $39.96 \pm 4.673$ ) and in non-smokers range between $31-52$ (42.74 \pm 4.526 ). Statistically, this difference is significant ( $p$ value < .05). In our study, mean value of SBP in smokers ranges between 120 - 146 (mean $131.83 \pm 7.16$ ) and in non-smokers range between $119-144$ (129.80 \pm 5.4059$)$. Statistically, this difference is non-significant $(p$ value $<.05)$. In our study, mean value of DBP in smokers ranges between 70 - 86 (mean $77.58 \pm 4.669$ ) and in non-smokers range between $68-90$ $(77.96 \pm 5.92)$. Statistically, this difference is non-significant ( $p$ value $>.05)$. In our study, mean value of HR in smokers ranges between 70 - 93 (mean $83.76 \pm 5.766$ ) and in non-smokers range between $63-80$ (74.14 \pm 4.194$)$. Statistically, this difference is highly significant ( $p$ value <.001). In our study, mean value of RR interval in smokers ranges between $64-86$ (mean $7322 \pm .05304$ ) and in non-smokers range between $74-.93$ (.8180 \pm 04267$)$. Statistically, this difference is highly significant ( $p$ value $<.001)$. In our study, mean value of BMI in smokers ranges between 18.20 - 25.18 (mean $21.42 \pm 1.36$ ) and in non-smokers range between 21.10 28.50 (23.86 \pm 1.64$)$. Statistically, this difference is highly significant ( $\mathrm{p}$ value $<.001)$.
\end{abstract}

\section{CONCLUSION}

The data suggests that serum total cholesterol, LDL cholesterol, VLDL cholesterol, TG and HR were significantly higher in smokers as compared to non-smokers; serum HDL levels and BMI was significantly lower in smokers as compared to non-smokers, but there was no significant difference between SBP and DBP of smokers and non-smokers.

\section{KEYWORDS}

High-Density Lipoprotein Cholesterol; Low-Density Lipoprotein Cholesterol; Lipoproteins; Risk Factors; Smoking; Triglycerides; Body Mass Index; Blood Pressure.

HOW TO CITE THIS ARTICLE: Agarwal C, Gupta R, Rijhwani P, et al. Evaluate the effect of cigarette smoking in lipid profile, body mass index (BMI), blood pressure (BP), resting heart rate and RR interval in healthy smokers and compare it with non-smokers. J. Evolution Med. Dent. Sci. 2017;6(90):6362-6367, DOI: 10.14260/jemds/2017/1384 
'Financial or Other Competing Interest': None.

Submission 18-08-2017, Peer Review 01-11-2017,

Acceptance 08-11-2017, Published 20-11-2017.

Corresponding Author:

Dr. Rishabh Gupta,

S/o. Sutinder Pal Gupta,

Ward No. 1, Chandigarh Hospital,

Hanumangarh Junction, Hanumangarh

Rajasthan-335512.

E-mail: rishabh6190@gmail.com

DOI: $10.14260 /$ jemds $/ 2017 / 1384$

\section{(c) (i) $(5)$}

\section{BACKGROUND}

\section{Effects of Cigarette Smoking}

Smoking leads to rise in carbon monoxide 4 that causes damage to the endothelium leading to atherosclerosis. Smoking causes anoxaemia in the tissue and myocardium due to formation of carboxyhaemoglobin and also increases the platelet aggregation. ${ }^{5}$ Nicotine increases adrenaline from the adrenal cortex that causes increase in free fatty acids (FFA) and hepatic synthesis and secretion of cholesterol and very low density lipoprotein (VLDL) and TGL. 6 Smoking leads to decrease in oestrogen levels, which decreases HDL cholesterol concentration. ${ }^{7}$ Smoking leads to hyperinsulinaemia, which decreases the activity of lipoprotein lipase ${ }^{8}$ leading to increased concentration of LDL, VLDL and TGL in the serum.

Cigarette Smoking
$\downarrow$
Absorption of nicotine into the body
$\downarrow$
Secretion of catecholamines, cortisol and growth hormones
$\downarrow$
Activation of adenyl cyclase in adipose tissue
$\downarrow$
Lipolysis of stored TG and release of FFA into plasma
$\downarrow$
Release of FFA from adipose tissue TG into plasma bound to
albumin
$\downarrow$
Increased Hepatic synthesis of TG, VLDL-C
$\downarrow$
Increased Plasma TG, VLDL-C
$\downarrow$
Decrease HDL-Cholesterol

Chart 1. Chart showing a possible Mechanism by which Nicotine Absorbed from Cigarette Smoke may Elevate Plasma Lipids and Lipoproteins

Our study was a descriptive comparative study, a first of its kind in north western region of India. The aim of this study was to evaluate the effect of cigarette smoking in Lipid Profile, Body Mass Index (BMI), Blood Pressure (BP), Resting Heart Rate and RR interval in healthy smokers and compare it with non-smokers.

\section{MATERIALS AND METHODS}

\section{Design and Sampling/Design}

Descriptive comparative study.

\section{Sample Size}

50 male non-smokers in Group 1 and 50 male smokers in Group 2 were taken individually in each group.

\section{Samplings}

The study enrolled 50 male non-smokers in Group 1 and 50 male smokers in Group 2 are taken individually in each group with age group between age 20 - 45 years, attending the outpatient Department of Medicine at Mahatma Gandhi Medical College and Hospital, Jaipur.

\section{Sampling Procedure}

Patients were divided into two Groups as Group 1 and Group 2.

\section{Group 1}

In this group, 50 healthy male non-smokers (controls) in age group of 20 - 45 years were taken, attending Medicine Department at Mahatma Gandhi Medical College and Hospital, Jaipur.

\section{Group 2}

In this group 50 male smokers (cases) in age group of $20-45$ years were taken, attending Medicine Department at Mahatma Gandhi Medical College and Hospital, Jaipur.

\section{Inclusion Criteria}

50 healthy male subjects of age 20 - 45 years and 50 age matched male smokers attending Mahatma Gandhi Medical College and Hospital, who had the history of smoking one or more cigarette per day regularly for at least past one year. The sample size estimation was also done at conveniences.

\section{Exclusion Criteria}

Subjects with diabetes mellitus, ischaemic heart disease or peripheral vascular disease, chronic renal disease, any infectious or debilitating illness, taking antibiotics, steroids, thiazide diuretics, aspirin, non-steroidal anti-inflammatory drugs, immunomodulatory drugs and drugs that influence lipid level will be excluded from the study.

The subjects who are passive smokers, ex-smokers and those who underwent recent hospitalisation, surgery and radiotherapy will also be excluded.

Since smoking is extremely rare among women in this area due to cultural reasons, women were not included. Study by convenient sampling technique since the duration of the study was short duration. The sample size was selected by convenience sampling technique.

\section{Ethical Issues}

Ethical Clearance was Sought from Hospital Ethics Committee. Besides this-

1. Written consent was taken from patients participating in the study.

2. Confidentiality was maintained.

\section{Statistical Analysis}

100 patients participated in descriptive comparative study, which was conducted in Department of Medicine at Mahatma Gandhi Medical College and Hospital, Jaipur. Patients were divided into two groups as Group 1 (non-smokers) and Group 2 (smokers). All the included patients completed the study and were statistically analysed. The observations were tabulated in the form of mean \pm standard deviation (SD) and analysed using ' $\mathrm{t}$ ' test for intergroup comparison. Difference in categorical data was assessed by chi-square test $\left(\mathrm{x}^{2}\right)$. 
Comparison and level of significance was determined as its ' $p$ ' value with-

$\mathrm{p}>0.05$ - Insignificant.

$\mathrm{p}<0.05$ - Significant.

$\mathrm{p}<0.001$ - Highly Significant.

\section{RESULTS}

\begin{tabular}{|c|c|c|c|c|c|c|}
\hline Group & $\begin{array}{c}\text { Age (Years) } \\
\text { Mean } \pm \text { SD }\end{array}$ & $\begin{array}{c}\text { Total Cholesterol } \\
\text { Mean } \pm \text { SD }\end{array}$ & $\begin{array}{c}\text { LDL } \\
\text { Mean } \pm \text { SD }\end{array}$ & $\begin{array}{c}\text { VLDL } \\
\text { Mean } \pm \text { SD }\end{array}$ & $\begin{array}{c}\text { TG } \\
\text { Mean } \pm \text { SD }\end{array}$ & $\begin{array}{c}\text { HDL } \\
\text { Mean } \pm \text { SD }\end{array}$ \\
\hline Group 1 & $34.42 \pm 6.68$ & $161.64 \pm 11.18$ & $85.18 \pm 8.048$ & $17.588 \pm 1.03$ & $125.30 \pm 5.737$ & $42.74 \pm 4.526$ \\
\hline Group 2 & $34.42 \pm 6.76$ & $170.38 \pm 15.17$ & $118.44 \pm 35.770$ & $24.00 \pm 2.35$ & $149.58 \pm 46.141$ & $39.96 \pm 4.673$ \\
\hline P value & $0.964 ;$ NS & $0.001^{*} S$ & $<0.001^{* *} \mathrm{HS}$ & $<0.001^{* *} \mathrm{HS}$ & $<0.001^{* *} \mathrm{HS}$ & $0.003^{*} \mathrm{~S}$ \\
\hline \multicolumn{7}{|c|}{ Table A } \\
\hline
\end{tabular}

\begin{tabular}{|c|c|c|c|c|c|}
\hline Group & SBP Mean \pm SD & DBP Mean \pm SD & HR Mean \pm SD & RR Mean \pm SD & BMI Mean \pm SD \\
\hline Group 1 & $129.80 \pm 5.4059$ & $77.96 \pm 5.92$ & $74.14 \pm 4.194$ & $.8180 \pm .04267$ & $23.86 \pm 1.64$ \\
\hline Group 2 & $131.83 \pm 7.16$ & $77.58 \pm 4.669$ & $83.76 \pm 5.766$ & $.7322 \pm .05304$ & $21.42 \pm 1.36$ \\
\hline P value & $0.112 ;$ NS & $0.722 ;$ NS & $<0.001^{* *} \mathrm{HS}$ & $<0.001^{* *} \mathrm{HS}$ & $<0.001^{* *} \mathrm{HS}$ \\
\hline \multicolumn{7}{|c|}{ Table B } \\
\hline
\end{tabular}

\begin{tabular}{|c|c|c|c|c|c|}
\hline Group & No. & Range & $\begin{array}{c}\text { Age (Years) } \\
\text { Mean } \pm \text { SD }\end{array}$ & 't' value & P value \\
\hline Group 1 & 50 & $23-45$ & $34.42 \pm 6.68$ & \multirow{2}{*}{0.045} & $0.964 ;$ NS \\
\hline Group 2 & 50 & $23-45$ & $34.42 \pm 6.76$ & & \\
\cline { 1 - 3 } & &
\end{tabular}

Table 1. Age Wise Distribution of the Study Cases and Controls

NS: $p>0.05$; Not significant

Table No. 1 depicts age wise distribution of the cases and controls. In our study, 50 healthy male subjects and 50 age matched male smokers in range of 23 - 45 years are taken. Mean \pm SD is $34.42 \pm 6.68$. Statistically, this difference was insignificant $(\mathrm{p}>0.05)$. This result has been displayed in Graph No. 1.

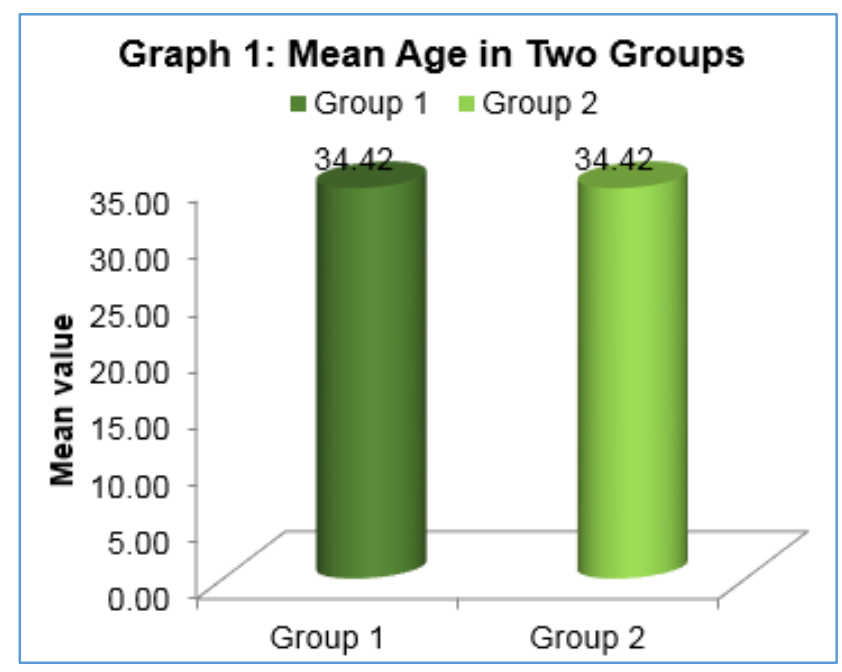

\begin{tabular}{|l|c|c|c|c|c|}
\hline Group & No. & Range & $\begin{array}{c}\text { Total Cholesterol } \\
(\mathbf{m g} / \mathbf{d L}) \text { Mean } \pm \text { SD }\end{array}$ & $\begin{array}{c}\text { 't' } \\
\text { value }\end{array}$ & $\begin{array}{c}\text { P } \\
\text { value }\end{array}$ \\
\hline Group 1 & 50 & $140-182$ & $161.64 \pm 11.18$ & 3.279 & $0.001 *$ \\
\hline Group 2 & 50 & $136-201$ & $170.38 \pm 15.17$ & & \\
\hline Table 2. Total Cholesterol in the Study Cases and Controls \\
\hline
\end{tabular}

$\mathrm{P}<0.05$; Significant
Table No. 2 depicts total cholesterol in the study cases and controls. In our study, the mean value of total cholesterol level in smokers ranges between $136-201$ (mean $170.38 \pm 15.17$ ) and in non-smokers range between $140-182$ (161.69 \pm 11.18). Statistically, this difference is significant ( $p$ value .001). This result has been displayed in Graph No. 2 .

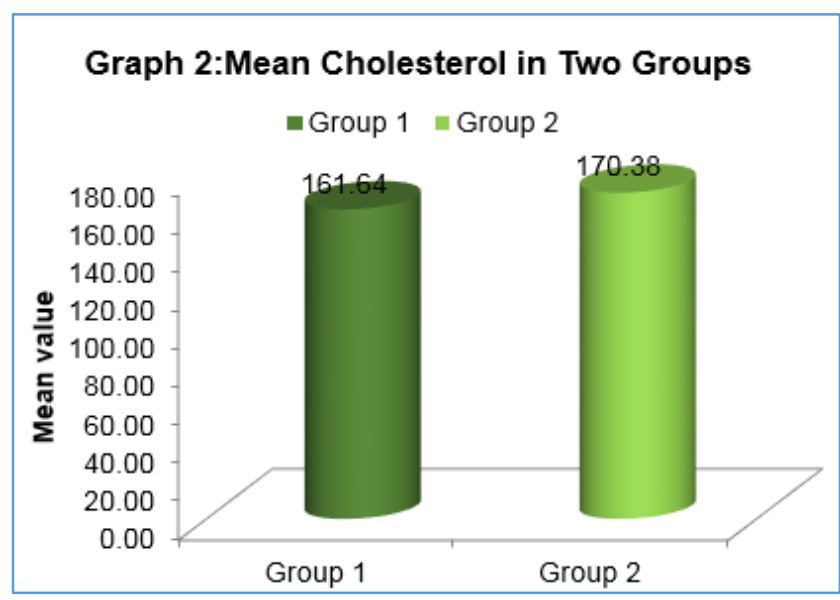

\begin{tabular}{|c|c|c|c|c|c|}
\hline Group & No. & Range & $\begin{array}{c}\text { LDL (mg/dL) } \\
\text { Mean } \pm \text { SD }\end{array}$ & \multirow{2}{*}{ 't' value } & P value \\
\hline Group 1 & 50 & $72-110$ & $85.18 \pm 8.048$ & \multirow{2}{*}{6.414} & $<0.001^{* *}$ \\
\hline Group 2 & 50 & $76-188$ & $118.44 \pm 35.770$ & & \\
\cline { 1 - 3 }
\end{tabular}

Table 3. Total LDL (Low Density Lipoproteins) in the Study Cases and Controls

${ }^{* *} \mathrm{p}<0.001 ;$ Highly significant.

Table No. 3 depicts comparison of mean values of LDL in the study cases and controls. In our study, the mean value of LDL cholesterol level in smokers ranges between 76 - 188 (mean $118.44 \pm 35.770$ ) and in non-smokers range between 72 - 110 (85.18 \pm 8.048$)$. Statistically, this difference is highly significant ( $p$ value $<.001)$. This result has been displayed in Graph No. 3. 


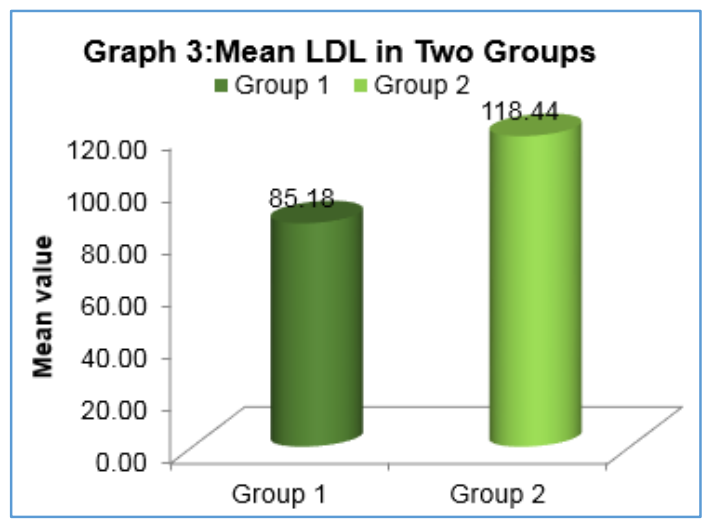

\begin{tabular}{|l|c|c|c|c|c|}
\hline Group & No. & Range & $\begin{array}{c}\text { VLDL (mg/dL) } \\
\text { Mean } \pm \text { SD }\end{array}$ & 't' value & P value \\
\hline Group 1 & 50 & $14-19$ & $17.588 \pm 1.03$ & \multirow{2}{*}{17.690} & $<0.001^{* *}$ \\
\hline Group 2 & 50 & $21-33$ & $24.00 \pm 2.35$ & & \\
\hline Table 4. Total VLDL (Very Low-Density Lipoproteins) in the \\
Study Cases and Controls \\
\hline
\end{tabular}

${ }^{* *} \mathrm{p}<0.001 ;$ Highly significant

Table No. 4 depicts comparison of mean values of VLDL in the study cases and controls. In our study, the mean value of VLDL cholesterol level in smokers ranges between 21 - 33 (mean $24 \pm 2.35$ ) and in non-smokers range between $14-19$ (17.5.888 \pm 1.03$)$. Statistically, this difference is highly significant ( $\mathrm{p}$ value $<.001$ ). This result has been displayed in Graph No. 4.

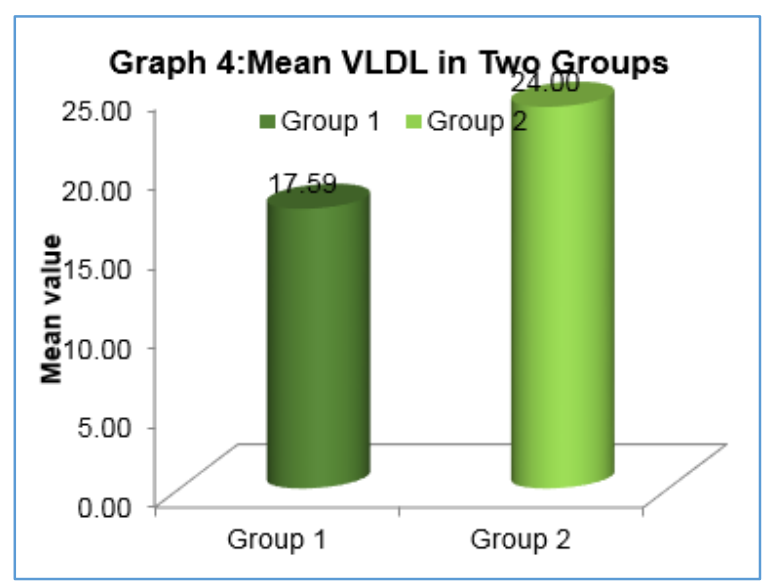

\begin{tabular}{|l|c|c|c|c|c|}
\hline Group & N & Range & $\begin{array}{c}\text { TG (mg/dL) } \\
\text { Mean } \pm \text { SD }\end{array}$ & 't' value & P value \\
\hline Group 1 & 50 & $110-136$ & $125.30 \pm 5.737$ & \multirow{2}{*}{3.692} & $<0.001^{* *}$ \\
\hline Group 2 & 50 & $120-226$ & $149.58 \pm 46.141$ & & \\
\hline \multicolumn{6}{|c|}{ Table 5. Total Triglyceride (TG) Level in the } \\
Study Cases and Controls \\
\hline
\end{tabular}

${ }^{* *} \mathrm{p}<0.001 ;$ Highly significant

Table No. 5 depicts comparison of mean values of triglyceride in the study cases and controls. In our study, the mean value of TG in smokers ranges between 120 - 226 (mean $149.58 \pm 46.141$ ) and in non-smokers range between $110-136(125.30 \pm 5.737)$. Statistically, this difference is highly significant ( $\mathrm{p}$ value $<.001$ ). This result has been displayed in Graph No. 5.
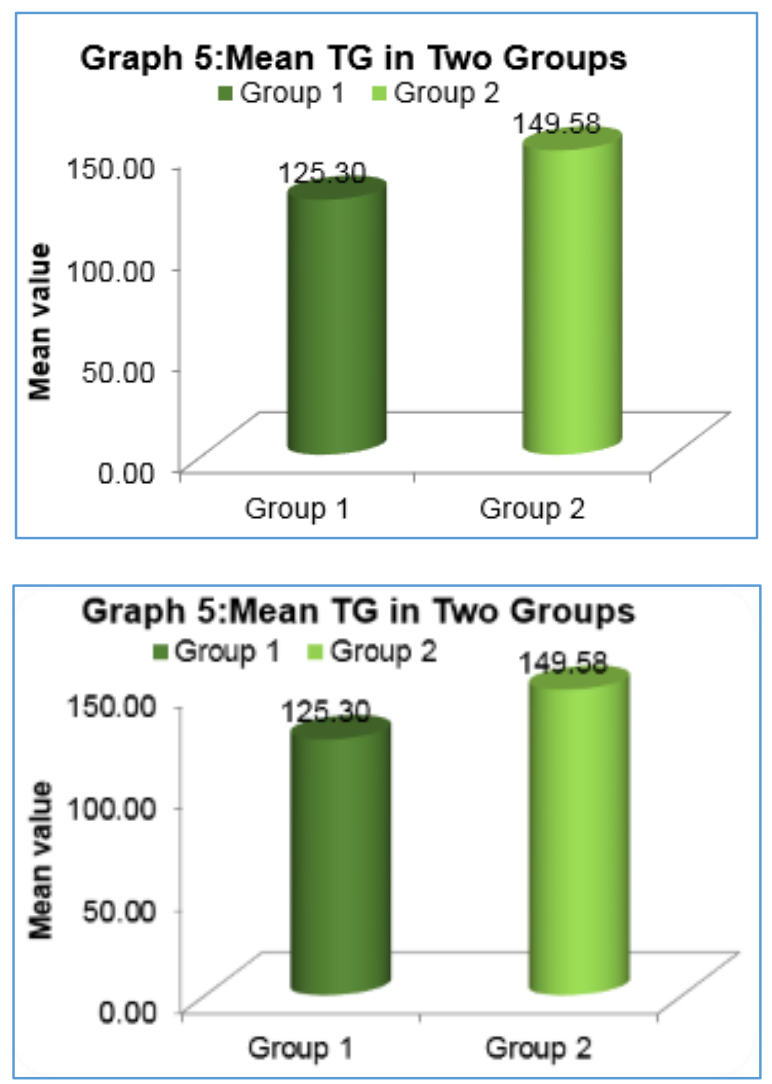

\begin{tabular}{|l|c|c|c|l|l|}
\hline Group & No. & Range & $\begin{array}{c}\text { HDL (mg/dL) } \\
\text { Mean } \pm \text { SD }\end{array}$ & 't' value & P value \\
\hline Group 1 & 50 & $31-52$ & $42.74 \pm 4.526$ & \multirow{2}{*}{3.022} & $0.003^{*}$ \\
\hline Group 2 & 50 & $27-47$ & $39.96 \pm 4.673$ & & \\
\hline Table 6. Total High-Density Lipoprotein (HDL) Level in the \\
Study Cases and Controls \\
\hline
\end{tabular}

Table No. 6 depicts comparison of mean values of triglyceride in the study cases and controls. In our study, mean value of HDL in smokers ranges between 27 - 47 (mean $39.96 \pm 4.673$ ) and in non-smokers range between $31-52$ (42.74 \pm 4.526$)$. Statistically, this difference is significant ( $p$ value $<.05)$. This result has been displayed in Graph No. 6 .

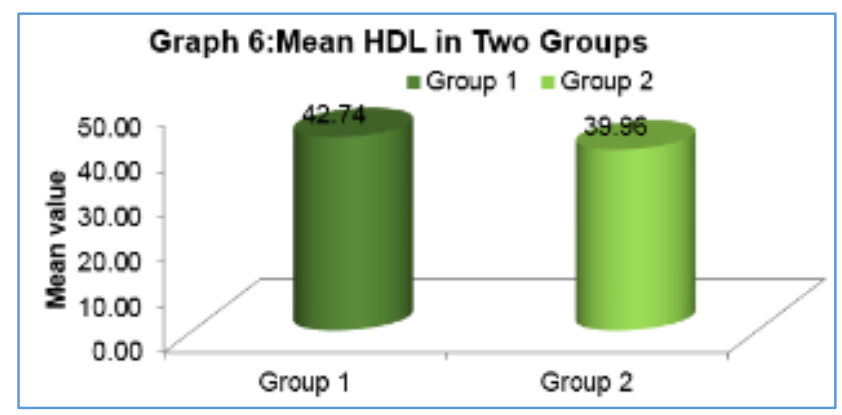

\begin{tabular}{|c|c|c|c|c|c|}
\hline Group & No. & Range & $\begin{array}{c}\text { SBP (mmHg) } \\
\text { Mean } \pm \text { SD }\end{array}$ & 't' value & P value \\
\hline Group 1 & 50 & $119-144$ & $\begin{array}{c}129.80 \pm \\
5.4059\end{array}$ & 1.603 & $0.112 ;$ NS \\
\cline { 1 - 4 } Group 2 & 50 & $120-146$ & $131.83 \pm 7.16$ & & \\
\hline Table 7. Systolic Blood Pressure (SBP) Level in the Study \\
Cases and Controls \\
\hline
\end{tabular}

NS: $p>0.05$; not significant 
Table No. 7 depicts comparison of mean values of SBP in the study cases and controls. In our study, mean value of SBP in smokers ranges between 120 - 146 (mean $131.83 \pm 7.16$ ) and in non-smokers range between $119-144$ (129.80 \pm 5.4059). Statistically, this difference is non-significant (p value <.05). This result has been displayed in Graph No. 7 .

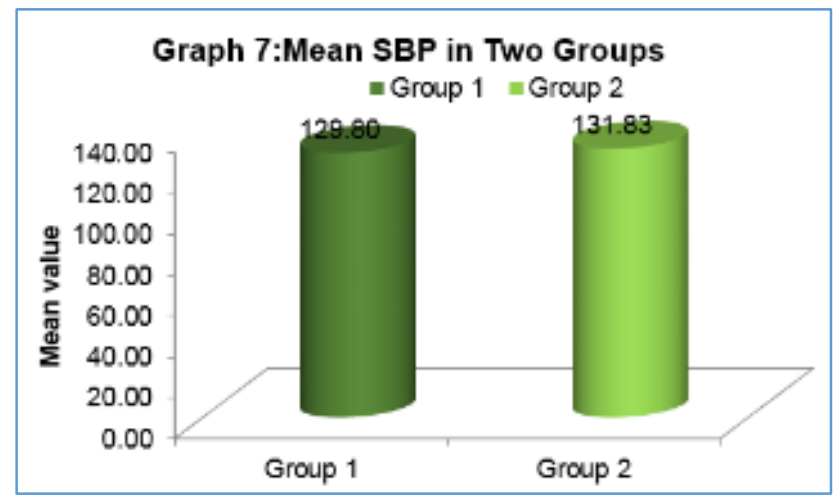

\begin{tabular}{|c|c|c|c|c|c|}
\hline Group & No. & Range & $\begin{array}{c}\text { DBP (mmHg) } \\
\text { Mean } \pm \text { SD }\end{array}$ & 't' value & P value \\
\hline Group 1 & 50 & $68-90$ & $77.96 \pm 5.92$ & \multirow{2}{*}{0.356} & $0.722 ; \mathrm{NS}$ \\
\hline Group 2 & 50 & $70-86$ & $77.58 \pm 4.669$ & & \\
\hline \multicolumn{7}{|c|}{ Table 8. Diastolic Blood Pressure (DBP) Level in } \\
the Study Cases and Controls \\
\hline
\end{tabular}

NS: $\mathrm{p}>0.05$; not significant

Table No. 8 depicts comparison of mean values of DBP in the study cases and controls. In our study, mean value of DBP in smokers ranges between $70-86$ (mean $77.58 \pm 4.669$ ) and in non-smokers range between 68 - 90 (77.96 \pm 5.92). Statistically, this difference is non-significant ( $p$ value $>.05$ ). This result has been displayed in Graph No. 8.

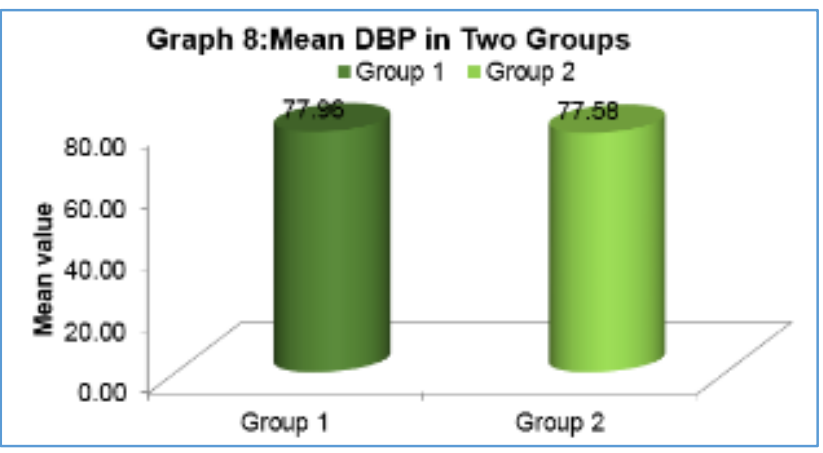

\begin{tabular}{|l|c|c|c|c|c|}
\hline Group & No. & Range & $\begin{array}{c}\text { HR (/minute) } \\
\text { Mean } \pm \text { SD }\end{array}$ & 't' value & P value \\
\hline Group 1 & 50 & $63-80$ & $74.14 \pm 4.194$ & 9.540 & $<0.001^{* *}$ \\
\hline Group 2 & 50 & $70-93$ & $83.76 \pm 5.766$ & & \\
\hline \multicolumn{7}{|c|}{ Table 9. Heart Rate in the Study Cases and Controls } \\
\hline
\end{tabular}

${ }^{* *} \mathrm{p}<0.001 ;$ Highly significant

Table No. 9 depicts comparison of mean values of heart rate in the study cases and controls. In our study, mean value of HR in smokers ranges between $70-93$ (mean $83.76 \pm$
5.766) and in non-smokers range between $63-80$ (74.14 \pm 4.194). Statistically, this difference is highly significant ( $p$ value <.001). This result has been displayed in Graph No. 9.

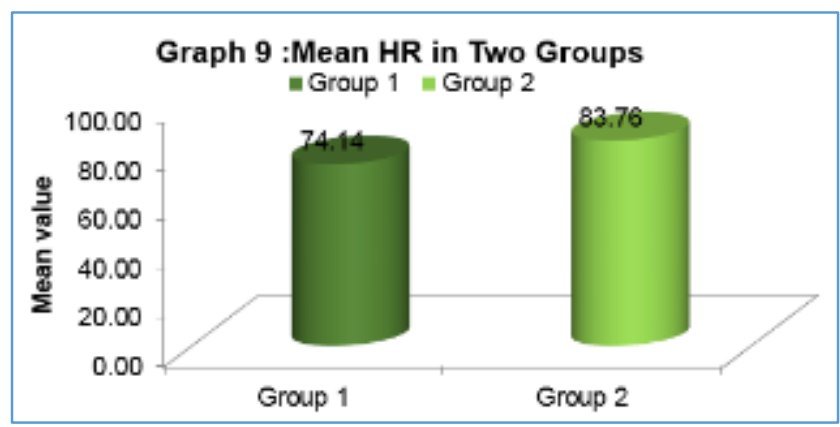

\begin{tabular}{|c|c|c|c|c|c|}
\hline Group & No. & Range & $\begin{array}{c}\text { RR } \\
\text { (milliseconds) } \\
\text { Mean } \pm \text { SD }\end{array}$ & 't' value & P value \\
\hline Group 1 & 50 & $.74-.93$ & $.8180 \pm .04267$ & \multirow{2}{*}{8.913} & $<0.001^{* *}$ \\
\cline { 1 - 4 } 2 & 50 & $.64-.86$ & $.7322 \pm .05304$ & & \\
\hline \multicolumn{7}{|c|}{ Table 10. RR Interval in the Study Cases and Controls } \\
\hline
\end{tabular}

${ }^{* *} \mathrm{p}<0.001$; Highly significant

Table No. 10 depicts comparison of mean values of RR interval in the study cases and controls. In our study, mean value of RR interval in smokers ranges between $.64-.86$ (mean .7322 \pm .05304 ) and in non-smokers range between $.74-.93(.8180 \pm 04267)$. Statistically, this difference is highly significant ( $\mathrm{p}$ value $<.001$ ). This result has been displayed in Graph No. 10.

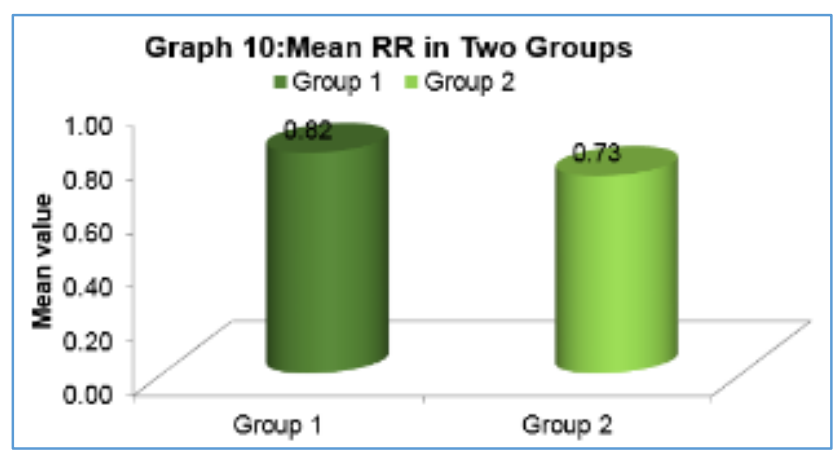

\begin{tabular}{|c|c|c|c|c|c|}
\hline Group & No. & Range & $\begin{array}{c}\text { BMI }\left(\mathbf{k g} / \mathbf{m}^{2}\right) \\
\text { Mean } \pm \text { SD }\end{array}$ & 't' value & P value \\
\hline Group 1 & 50 & $21.10-28.50$ & $23.86 \pm 1.64$ & \multirow{2}{*}{8.099} & $<0.001^{* *}$ \\
\cline { 1 - 4 } Group 2 & 50 & $18.20-25.18$ & $21.42 \pm 1.36$ & & \\
\hline \multicolumn{5}{|c|}{ Table 11. Body Mass Index (BMI) in the Study } \\
Cases and Controls
\end{tabular}

${ }^{* *} \mathrm{p}<0.001 ;$ Highly significant

Table No. 11 depicts comparison of mean values of BMI in the study cases and controls. In our study, mean value of BMI in smokers ranges between 18.20 - 25.18 (mean $21.42 \pm 1.36$ ) and in non-smokers range between $21.10-28.50$ (23.86 \pm 1.64). Statistically, this difference is highly significant ( $\mathrm{p}$ value $<.001)$. This result has been displayed in Graph No. 11 . 


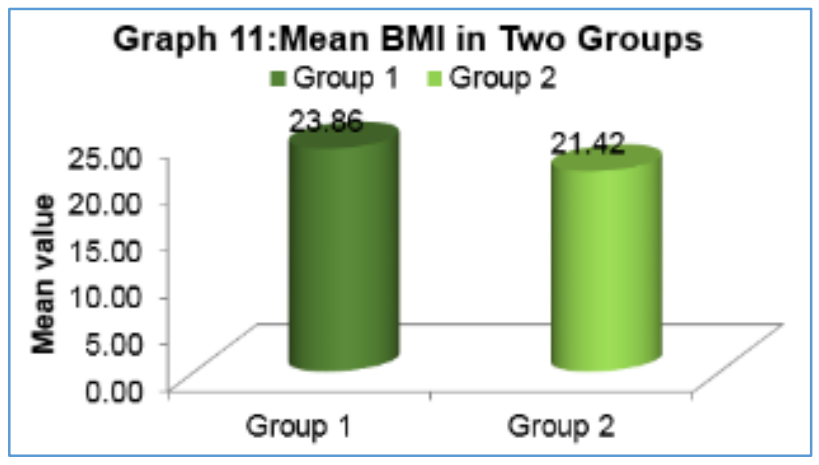

\section{DISCUSSION}

In our study, the mean total cholesterol in smokers was $170.38 \pm 15.17 \mathrm{mg} / \mathrm{dL}$ and in non-smokers was $161.64 \pm$ $11.18 \mathrm{mg} / \mathrm{dL}$. In a study conducted by Singh D on Effect of Cigarette Smoking on Serum Lipid Profile, it was revealed that mean serum total cholesterol $(268.88 \pm 29.23 \mathrm{mg} / \mathrm{dL})$ were significantly higher in chronic smokers as compared to nonsmokers. ${ }^{9}$

In our study, mean LDL cholesterol in 50 smokers was $118.44 \pm 35.770 \mathrm{mg} / \mathrm{dL}$. Statistically, this difference is highly significant ( $p$ value $<.001$ ). In our study, mean value of HDL in smokers ranges between $27-47$ (mean $39.96 \pm 4.673$ ). Statistically, this difference is significant ( $\mathrm{p}$ value $<.05$ ). In a similar study conducted by Ramachandran Meenakshisundara, there was a rise in TC, TGL, LDL, Apo-B and fall in HDL and Apo-A; these changes were significant (P $<0.05) .10$

In our study, mean TG in 50 smokers was $149.58 \pm 46.141$ $\mathrm{mg} / \mathrm{dL}$. In study conducted by NS Neki, average triglycerides among mild smokers was $171.5+/-32.42 \mathrm{mg} \%$ and among non-smokers it was $121.2+/-32.7 \mathrm{mg} \% .{ }^{11}$

In our study, mean value of HR in smokers ranges between $70-93$ (mean $83.76 \pm 5.766$ ) and in non-smokers range between $63-80$ (74.1f4 \pm 4.194$)$. Statistically, this difference is highly significant ( $p$ value $<.001$ ). In a similar study conducted by Junichi Minami, the 24-hour heart rate was significantly lower in the non-smoking period than in the smoking period by $7.3 \pm 1.0$ beats $/ \min (\mathrm{P}<0.0001) .12$

In our study, mean value of RR interval in smokers ranges between $.64-.86$ (mean .7322 \pm .05304$)$ and in non-smokers range between $.74-.93(.8180 \pm .04267)$. Statistically, this difference is highly significant ( $p$ value $<.001$ ) (Table 10). In a study conducted by MR Renuka Devi, the RR interval, the QT interval and the ST segment were shortened in the smokers as compared to those in the non-smokers, which was highly significant statistically. ${ }^{13}$

In our study, mean value of BMI in smokers ranges between 18.20 - 25.18 (mean $21.42 \pm 1.36$ ) and in nonsmokers range between $21.10-28.50$ (23.86 \pm 1.64). Statistically, this difference is highly significant ( $\mathrm{p}$ value $<$ .001) (Table 11). In a similar study conducted by Plurphanswat and Rodu on the association of smoking and demographic characteristics on body mass index and obesity among adults in the US compared to never smokers, men and women current smokers had lower BMI and lower probability of obesity.

\section{CONCLUSION}

The data suggests that serum total cholesterol, LDL cholesterol, VLDL cholesterol, TG and HR were significantly higher in smokers as compared to non-smokers, serum HDL levels and BMI was significantly lower in smokers as compared to non-smokers, but there was no significant difference between SBP and DBP of smokers and nonsmokers.

\section{Limitation of the Study}

Due to short duration of study, convenience sampling technique was followed. Thus, sampling size was also calculated by convenience. The results of the study cannot be generalised due to the potential bias resulting from the sampling technique and sample size estimation.

\section{REFERENCES}

[1] Guedes DP, Guedes JERP, Barbosa DS, et al. Tobacco use and plasma lipid-lipoprotein profile in adolescents. Rev Assoc Med Bras 2007;53(1):59-61.

[2] Aggarwal A, Aggarwal S, Sarkar PG, et al. Predisposing factors to premature coronary artery disease in young (age $\leq 45$ years) smokers: a single center retrospective case control study from India. J Cardiovasc Thorac Res 2014;6(1):15-9.

[3] Murray CJ, Lopez AD. The global burden of disease: a comprehensive assessment of mortality and disability from diseases, injuries and risk factors in 1990 and projected to 2020. Cambridge, Massachussets: Harvard School of Public Health, 1996.

[4] Sagcan A, Akin M, Omay B, et al. In-vitro-response of platelet aggregation induced by various agonists in chronic smoking coronary artery disease patients. J Clin Basic Cardiol 2003;6(1-4):55-7.

[5] Muscat JE, Harris RE, Haley NJ, et al. Cigarette smoking and plasma cholesterol. Am Heart J 1991;121(1 Pt 1):141-7.

[6] Benowitz NL. Drug therapy. Pharmacologic aspects of cigarette smoking and nicotine addiction. N Engl J Med 1988;319(20):1318-30.

[7] Stalder M, Pometta D, Suenram A. Relationship between plasma insulin levels and HDL-cholesterol levels in healthy men. Diabetologia 1981;21(6):544-8.

[8] Singh D. Effect of cigarette smoking on serum lipid profile in male population of udaipur. Int J Clin Bio Res 2016;3(4):368-70.

[9] Meenakshisundaram R, Rajendiran C, Thirumalaikolundusubramanian P. Lipid and lipoprotein profiles among middle aged male smokers: a study from southern India. Tob Induc Dis 2010;8:11.

[10] Neki NS. Lipid profile in chronic smokers-a clinical study. J Indian Academy of Clinical Medicine 2002;3(1):51-4.

[11] Minami J, Ishimitsu T, Matsuoka H. Effects of smoking cessation on blood pressure and heart rate variability in habitual smokers. Hypertension 1999;33(1 Pt 2):586-90.

[12] Devi MR, Arvind T, Kumar PS. ECG changes in smokers and non smokers-a comparative study. J Clin Diagn Res 2013;7(5):824-6.

[13] Plurphanswat N, Rodu B. The association of smoking and demographic characteristics on body mass index and obesity among adults in the US, 1999-2012. BMC Obes 2014;1:18. 